\section{Percutaneous vertebroplasty: a comparison between the procedure using the traditional and the new side-opening cannula for osteo- porotic vertebral fracture (Abstract) ${ }^{*}$. Thesis. Brasília, 2009.}

\section{Nicandro de Figueiredo Neto**}

Percutaneous vertebroplasty (PV) is a minimally invasive procedure used to treat focal pain of osteoporotic vertebral fractures, osteolytic metastatic disease, myeloma and aggressive hemangioma. PV has some potential complications: the most common are caused by cement extrusion, usually asymptomatic, but may lead to clinical complications, such as radicular or spinal cord compression and lung embolism. A new cannula for cement injection was developed by Heini and Allred, by closing the frontal aperture and opening a lateral one, close to the tip of the traditonal cannula. This allows the flow of cement to be redirected medially, thus reducing the risk of cement extravasation and increasing the safety of the procedure.

Study Design: A clinical, single-blinded, randomized study, about a new cannula for percutaneous vertebroplasty.

Objective: To analyze the safety and efficacy of a new cannula with lateral opening, especially the reduction of cement extravasation during the injection and the pain control.

Method: This study included procedures of PV performed for osteoporotic vertebral fractures, using the frontal-opening and the new side-opening cannula, and the results were compared, aiming to detect mainly the difference between the two cannulas regarding the incidence of cement extravasation and the clinical outcome.

Results: A total of 47 PVs, performed from March 2003 to February 2008, were performed for osteoporotic vertebral fractures in 31 patients, 25 PVs were performed using the frontal-opening and 22 using the new side-opening cannula, randomly distributed. The incidence of cement extrusion was $27 \%$ with the side-opening cannula, and $68 \%$ with the frontal-opening, all asymptomatic $(\mathrm{p}<0.01)$. The pain control was very hight and similar for both groups, and there were no clinical complications.

Conclusion: Percutaneous vertebroplasty seems to be a very safe and efficacious pain relieving procedure for patients with osteoporotic vertebral fracture. Cement leakage is very common, usually asymptomatic, but there is a potential for clinical complications. This leakage can be significantly reduced with this new side opening cannula, which allows for a better cement injection toward the center of the vertebral body and increases the safety of the procedure with no elevation in cost.

Key words: percutaneous vertebroplasty, osteoporotic vertebral fracture, side opening cannula, bone cement extrusion, complications of vertebroplasty.

\footnotetext{
*Vertebroplastia percutânea: comparação do procedimento com a cânula tradicional e com a nova cânula de orifício lateral para fratura osteoporótica da coluna vertebral (Resumo). Tese de Doutorado. Universidade de Brasília UnB (Área de concentração: Neuroendocrinologia; Sub-área: cirurgia da coluna vertebral). Orientador: Luiz Augusto Casulari Roxo da Motta.

** Address: Av. das Flores, 941 / INEC - 78020-670 Cuiabá MT - Brasil. E-mail: nicandro2@yahoo.com
}

Depressive symptoms and cognitive functions in children with developmental dyslexia (Abstract). Dissertation. Campinas, 2011.

\section{Ricardo Franco de Lima**}

Objective: The aim of this work was to evaluate depressive symptoms and cognitive functions of attention and executive functions in children with dyslexia and children without learning disabilities.

Method: A sample of 61 children, aged between 7 and 14 years old, was divided into two groups: (A) 31 children diagnosed with dyslexia at Learning Disabilities Ambulatory - Hospital de Clínicas; (B) 30 children without learning disabilities evaluated at a public school. Individual evaluations were performed using the following instruments: Children Behavior Checklist, Children's Depression Inventory, Wechsler Intelligence Scale for Children, Cancellation Test, Trail Making Test, Stroop Test, Tower of London, Wisconsin Test, and the Verbal Fluency Test.

Results and Discussion: There were significant differences between groups in scores of different instruments. Correlations between scores of depressive symptoms and attention and executive functions tests were also observed. The findings indicate that parents of dyslexic children reported greater frequency of emotional symptoms, and these children are more vulnerable to depressive symptoms. They have shown alterations in attention and in some skills of executive functions: flexibility, inhibitory control, cognitive strategies, working memory, and verbal fluency. Correlations obtained suggest that depressive symptoms may negatively influence on cognitive functions.

Conclusion: These aspects should be investigated in the diagnosis of dyslexia and considered in the intervention process.

Key words: neuropsychology, neuropsychological tests, learning disabilities, dyslexia, depression.

\footnotetext{
*Sintomas depressivos e funções cognitivas em crianças com dislexia do desenvolvimento (Resumo). Universidade Estadual de Campinas. Departamento de Psicologia Médica e Psiquiatria (Dissertação de Mestrado em Ciências Médicas - Área Ciências Biomédicas). Campinas SP. Orientadora: Sylvia Maria Ciasca. Coorientadora: Cíntia Alves Salgado Azoni.

Support: This work was supported by the National Council for Scientific and Technological Development (CNPq)

**Address: R. Jorge Miranda, 104/ 43 - 13020-180 Campinas SP - Brasil. E-mail: rilima@fcm.unicamp.br.
} 